\title{
Growing and Training Effective Faculty
}

\section{Dr. Ronald W. Welch, The Citadel}

Ron Welch (P.E.) received his B.S. degree in Engineering Mechanics from the United States Military Academy in 1982. He received his M.S. and Ph.D. degrees in Civil Engineering from the University of Illinois, Champaign-Urbana in 1990 and 1999, respectively. He became the Dean of Engineering at The Citadel on 1 July 2011. Prior to his current position, he was the Department Head of Civil Engineering at The University of Texas at Tyler from Jan 2007 to June 2011 as well as served in the Corps of Engineers for over 24 years including eleven years on the faculty at the United States Military Academy.

\section{Ally Kindel Martin, The Citadel}

Ally Kindel Martin is the Director of Student Engagement, Projects \& Finance in the School of Engineering. In her position, she has worked with the Supplemental Instruction program, launched STEM Freshmen Outreach initiatives, created an Engineering Mentor Connection program, and revitalized the Engineering Career \& Networking Expo. She holds a M.Ed. in Higher Education and Student Affairs from the University of South Carolina. Previously she worked as a Student Success Adviser and focused on early intervention initiatives. She has taught courses including First Year Seminar, Keys to Student Success and University 101.

\section{Dr. Robert J. Rabb P.E., The Citadel}

Robert Rabb is an associate professor and the Mechanical Engineering Program Director at The Citadel. He previously taught mechanical engineering at the United States Military Academy at West Point. He received his B.S. in Mechanical Engineering from the United States Military Academy and his M.S.E. and $\mathrm{PhD}$ in Mechanical Engineering from the University of Texas at Austin. His research and teaching interests are in mechatronics, regenerative power, and multidisciplinary engineering.

\section{Dr. Kevin C Bower PE, The Citadel}

Dr. Kevin Bower is a Professor and Head of the Department of Civil and Environmental Engineering at The Citadel, Charleston, South Carolina. Dr. Bower's teaching research interests are in improving active learning environments and the development of classroom pedagogy to improve moral development in engineering students. 


\section{Growing and Training Effective Faculty}

The Citadel has a faculty development and training model (conference or workshop travel grants, research grants, presentation travel grants) that not only provides effective mentoring of new faculty, but reinvigorates senior faculty. The model uses the ASCE ExCEEd Teaching Workshop to mentor and enhance teaching effectiveness while providing faculty development funds to enhance external development opportunities, research, and research presentation by the faculty, staff, and students. The program has been used over the past five years and has dramatically enhanced the quality of education based on student assessment, but also has greatly increased the scholarship production of the faculty at a primarily teaching focused school. The data will be presented and analyzed with the result being best practices that can be used at most schools to improve teaching and scholarship production.

\section{Introduction}

Faculty development is normally self-directed if the faculty member is self-sufficient in obtaining funding. This works well for tier one research schools where success is built on average teaching and superior fund raising and scholarship production. These new faculty are given generous startup funds to support initiation of research (equipment, graduate student salaries, conference travel, faculty development, etc.). Consistently, most funds are used to support equipment purchases, student researcher salaries and faculty summer funding leaving little for professional development beyond attending conferences to present research, network, and/or learn about future research opportunities. In general, if the teaching is bad enough to rise to the attention of the department head or dean, additional funds are set aside to support teaching faculty development. Two of the best known workshops for civil engineering faculty are the National Effective Teaching Institute (NETI) ${ }^{1}$ and the ASCE Excellence in Civil Engineering Education (ExCEEd) ${ }^{2}$ Teaching Workshops. The School of Engineering at The Citadel uses the content within the ExCEEd Teaching Workshop for teaching faculty development.

Based on the recent American Association of Colleges and Universities (AACU) Provost and Deans list serve discussion (Fall 2016), the amounts for faculty development in small to medium sized departments vary by university and range from $\$ 500$ - \$1500 annually per faculty member. In large researched focused schools, faculty must generate their own development funds. In some schools, the faculty development funds are centralized at the Dean or Provost level and faculty submit a request. However, many programs have the amount added to their operating funds to support faculty development opportunities. The amount is normally so small that many department heads either provide all a small stipend to cover some of the travel or consolidate to use for the greater good of the entire faculty as determined by the department head or a vote of the faculty. An example of the best use could be teaching faculty development for new faculty since teaching is a primary focus at a majority of small to medium sized schools (with an accepted faculty workload model: $60 \%$ teaching, 20\% scholarship, and $20 \%$ for service). ${ }^{3}$

The Citadel was established as a teaching focused school where teaching was 90-100 percent of the faculty load with normally some service or scholarship filling the balance of available 
time. This focus can be observed within the faculty handbook where post tenure focuses on excellence in teaching and satisfactory activity in either service or scholarship. ${ }^{4}$ The faculty was nearly $90 \%$ tenured or tenure-tracked ten years ago. In order to broaden the faculty with the available funding through The Citadel Foundation, which was established nearly twenty years ago, a faculty grant was establish to provide funding for faculty development through the Provost's office. Faculty could apply through separate faculty led committees for $\$ 3000$ for research/scholarship, \$2500 for research presentation, and \$2500 for faculty development (workshop, conference attendance) per year. This program was marginally successful to support new tenure-track and some associate professors as they maintained a more balanced workload focus (closer to the 60-20-20 than the average norm of 90-5-5). Suchan et. al. addresses the issues of high faculty turnover and describes the commitment required of the institution to implement a faculty development model. ${ }^{5}$ Whether an institution is a research or teaching focused institution, there is an ABET requirement for faculty professional development (ABET, Criterion 6). The School of Engineering at The Citadel implemented a school-wide faculty development model.

In recent years with the greening of the faculty through expansion of programs and retirements, the academic leadership team decided to move all tenured and tenure-track faculty to the more accepted 60-20-20 faculty workload model. This change with a nearly 50 percent greening of the faculty will increase the visibility of the faculty at conferences and in proceedings and journals; thereby, hopefully increasing the visibility and acceptance rate of our increasing number of undergraduate students desiring to attend graduate school. Peer recognition is important in the acceptance of students into graduate school. While still feeling the effects of the recession on endowments and the need to support more research/scholarship and service by the tenure-track and tenured faculty under the new faculty workload model, the nearly $95 \%$ tenured or tenure-track faculty is being reshaped to be $75 \%$ tenured or tenure-tracked and $25 \%$ adjunct or lecturer (non-tenure track) over the next 5-10 years.

\section{Current Faculty Development Model}

There are numerous articles on the effect the recent recession had on decreasing state funding for higher education and returns on endowments. These forces resulted in a freezing of the availability of faculty development funds at The Citadel at pre-recession funding levels which the faculty led committees never knew existed. With the synergistic greening of the faculty, a need to responsibly spread the limited but available faculty development funds, and the implementation of the new faculty workload model, the School of Engineering set up a faculty development distribution model to effectively use available financial capabilities and move toward a more self-sufficient faculty development model. A slight change was made to the available amounts: up to $\$ 3000$ for one research/scholarship project, up to $\$ 2500$ for only one research presentation, and up to $\$ 2500$ for only one faculty development opportunity (workshop, conference attendance) per year and only with a detailed professional development plan established with the department head prior to the current year of funding. Additionally, new assistant professors could apply for one grant in each area, associate professors on track to achieving full professor could apply for two out of the 
three grants and full professors and long-term associate professors could only apply for one out of the three faculty development grants.

Initially the full and long-term associate professors expressed concern at the loss of an expected college-wide benefit. However, further research into benefit use noted that it was only available for about 10 years to include the recession years and many of the faculty were not taking advantage of it. The allocations for the School of Engineering showed over a five year period that the average annual amount used was approximately $\$ 30,000$ versus the possible full use in each area each year would have been $\$ 144,000$ or only 20.8 percent usage of the theoretically available funds. In actuality, there were never enough funds to provide full use of the benefits by each faculty member, committees were simply not provided a budget until the recession years and faculty greening exposed the actual limitations of the grant. Additionally only a few faculty used more than two out of the three available grants. With the greening of the faculty resulting in more need for faculty development funds for promotion and tenure support, the available funds being allocated based on previous usage of funds left each school short on funds versus demand. Until additional fund raising can increase availability to overcome dramatic decreases in state funding due to changes in postsecondary education support at the state level and limited endowment growth, if any, during the most recent recession, the allocation plan presented in the paragraph above was initiated.

The use of this funding model as well as the emphasis of a 60-20-20 load model has had dramatic impact on research, scholarship, and student recruiting and retention. It could be assumed that limiting the amount of faculty funding would negatively affect the performance of the faculty. However, Boice stated that typical new faculty take approximately $4+$ years to become productive in research and effective in teaching. With a good faculty development program that level can be attained in less than two years. ${ }^{6}$ Figure 1 and Tables $1-2$ depict the improvements during this time.

Currently there are 30 faculty in the School of Engineering with all but three teaching a four course/section load each semester. These three faculty are teaching a 3 course/section load each semester because they have been awarded a large research grant (NSF) or are consistently being awarded a number of small grants each year. Scholarship is classified using the following scale: 6 points for book/manuscript, 5 points for edited volume, 4 points for book chapter/book edition, 3 points for peer reviewed journal, 2 points for research/technical report, 1 point for peer reviewed conference paper and presentation, 0.5 points for non-peered reviewed conference paper and presentation, 0.25 points for presentation only. The goal of this point system is to visibly increase the amount of scholarship while determining the average scholarship amount for motivational effect. All new faculty (15 since 2012) have attended a Mini-ExCEEd teaching workshop taught by one of the authors and four of these have attended the week-long ExCEEd. These same new faculty are the primary foundation of faculty modifying and invigorating the freshmen courses. The institution tracks student evaluations by department and these new faculty are at or exceeding the departmental averages for each of their courses. 


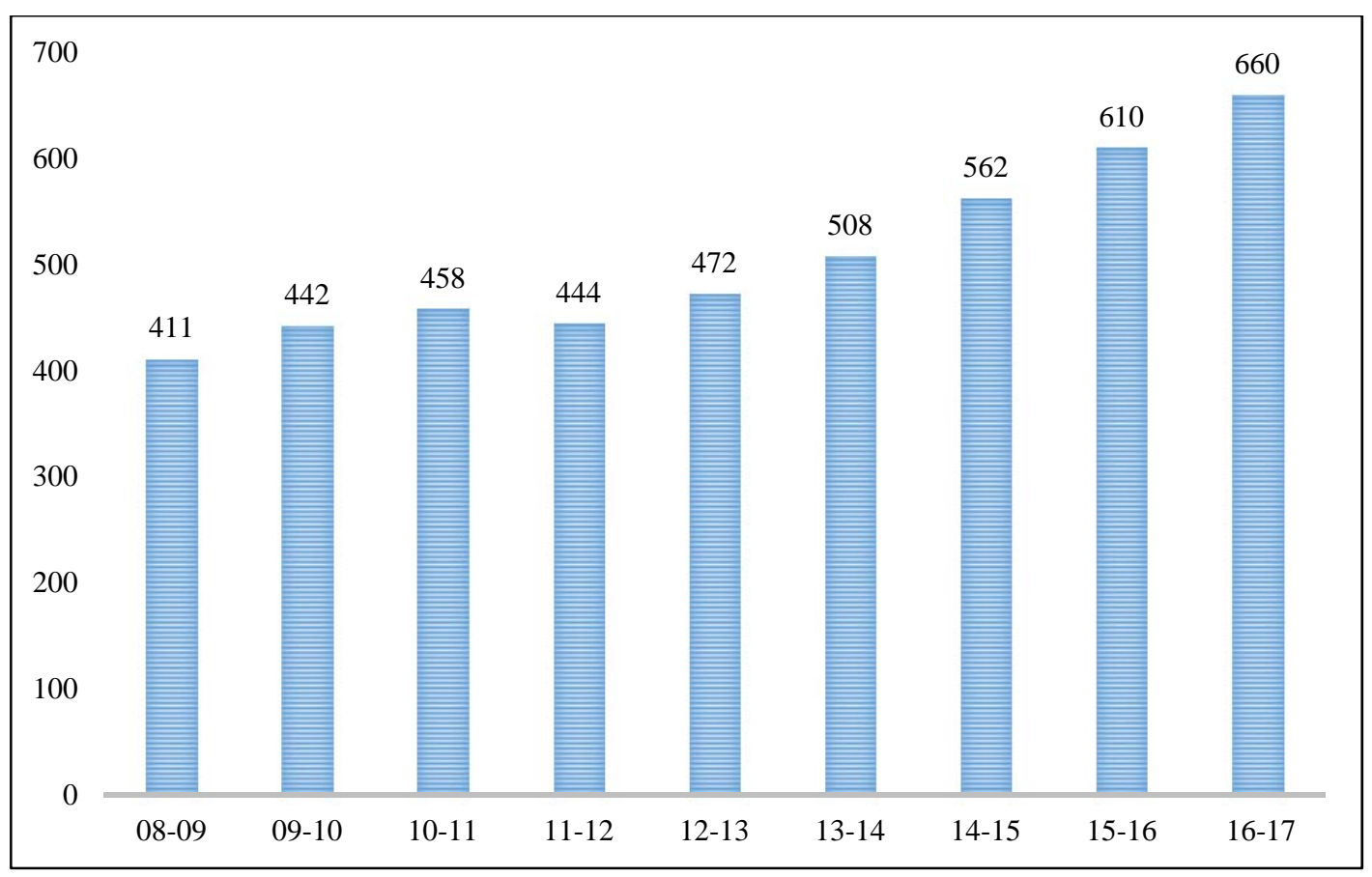

Figure 1. School of Engineering Undergraduate Student Growth from 2008-2016 ${ }^{7}$

Table 1. School of Engineering Faculty Workload and Scholarship Production 2011-2016

\begin{tabular}{|c|c|c|c|c|}
\hline Year & $\begin{array}{c}\text { Student Credit } \\
\text { Hour/faculty }\end{array}$ & Advisees/ Faculty & $\begin{array}{c}\text { Scholarship Total } \\
\text { School Wide }\end{array}$ & $\begin{array}{c}\text { Scholarship } \\
\text { Average/ Faculty }\end{array}$ \\
\hline 2012 & 349.7 & 27.4 & 47.5 & 2.2 \\
\hline 2013 & 358.7 & 30.5 & 41 & 1.7 \\
\hline 2014 & 366.7 & 29.6 & 89.8 & 3.2 \\
\hline 2015 & 374.2 & 29.9 & 101.5 & 3.7 \\
\hline 2016 & 369.1 & 22.0 & 146.3 & 4.6 \\
\hline
\end{tabular}

Note: Increased faculty by 12 since 2012.

Table 2. School of Engineering Faculty Research Proposal/Funding Production 2011-2016 ${ }^{8}$

\begin{tabular}{|c|c|c|c|}
\hline & Proposals Submitted & Requested Funding & Funding Expended \\
\hline 2011 & 0 & & \\
\hline 2012 & 2 & & $\$ 197,070.00^{*}$ \\
\hline 2013 & 3 & & $\$ 361,081.00^{*}$ \\
\hline 2014 & 6 & & $\$ 240,097.00^{*}$ \\
\hline 2015 & 8 & $\$ 3,640,000.00$ & $\$ 161,077.00^{*}$ \\
\hline 2016 & 11 & $\$ 7,906,850.00$ & $\$ 225,424.00$ \\
\hline
\end{tabular}

*These funds are primarily from a \$600k NSF S-STEM grant submitted in 2010 and the internal grants for research (\$3000) noted above. 
This growth founded on requiring professional development plans that match tenure and promotion goals have led to greater research proposal submission and funding, scholarship, and growth in student enrollment which has ultimately led to new faculty lines. The actual availability of these funds ten years ago did not generate the faculty development envisioned. The fact that the resources are now limited, the college is moving to a 60-20-20 faculty workload model, and an actual justification for applying for the available funds is now a requirement has generated more research, scholarship, and enrollment growth. A benefit of the increased research and student enrollment growth is as follows (Figure 2 and Table 3):

- Expansion of undergraduate research which has nearly quadrupled even at a teaching focused school.

- Over 50 percent of these projects result in a conference paper with the undergraduate student.

- Nearly 10 percent result in a journal paper.

- Students travel with the faculty member to present the paper.

- All of these undergraduate research projects results in a student poster during the campus-wide undergraduate research conference.

- Faculty conducting undergraduate research are also completing their own research with publication that the undergraduate research supports (about 20 percent).

Table 3. School of Engineering Undergraduate Research projects

\begin{tabular}{|c|c|}
\hline Semester/Year & Subject \\
\hline Fa10-Sp11 & SC Dept of Transportation Pavement Marking Resender \\
\hline Fa11-Sp12 & Battery 2 Beach \\
\hline Fa11-Sp12 & Assembler for an Instructional Processor \\
\hline Fa13 & MathCad as Teaching Tool in Structural Analysis \\
\hline Fa12-Sp13 & Data \& Image Compression \\
\hline Fa12-Sp13 & Wavelet Image Compression \\
\hline Fa12-Sp13 & Roundabouts and Access Management \\
\hline Su14-Fa14 & State Earthquake Assistant \\
\hline Su14 & Evaluation of an Ultra-Wideband Diplexer for Simultaneous \\
\hline Fa14-Sp15 & UHF and X-Band Operation using Modulated Gaussian Pulses \\
\hline Fa14-Sp15 & An Effective Student Implemented STEM Outreach Program \\
& for Title 1 Schools \\
\hline Sp15 & Half-Wave Parabolic Reflector Antenna Optimization \\
\hline Su15 & State Earthquake Assistant \\
\hline Fa15 & Development of a Fluid Mechanics Concept Inventory for Civil \\
Engineers
\end{tabular}




\begin{tabular}{|c|c|}
\hline Sp16 & Wave Dissipation System \\
\hline Fa16 & Radio Frequency Bandpass Filter \\
\hline Fa16 & AM Modulator and Demodulator \\
\hline Fa16 & FM Demodulator \\
\hline Sp16-Fa16 & $\begin{array}{c}\text { Navigation of Pedestrians and Bicycles at Roundabouts and its } \\
\text { Impact to Vehicular Capacity }\end{array}$ \\
\hline Fa16 & $\begin{array}{c}\text { Introduce a Girl to Engineering Day: Assessment of Impact and } \\
\text { Future Directions }\end{array}$ \\
\hline Fa16-Sp17 & Fragility Analysis of Residential Developments Subjected to \\
Hurricane Wind Hazards
\end{tabular}

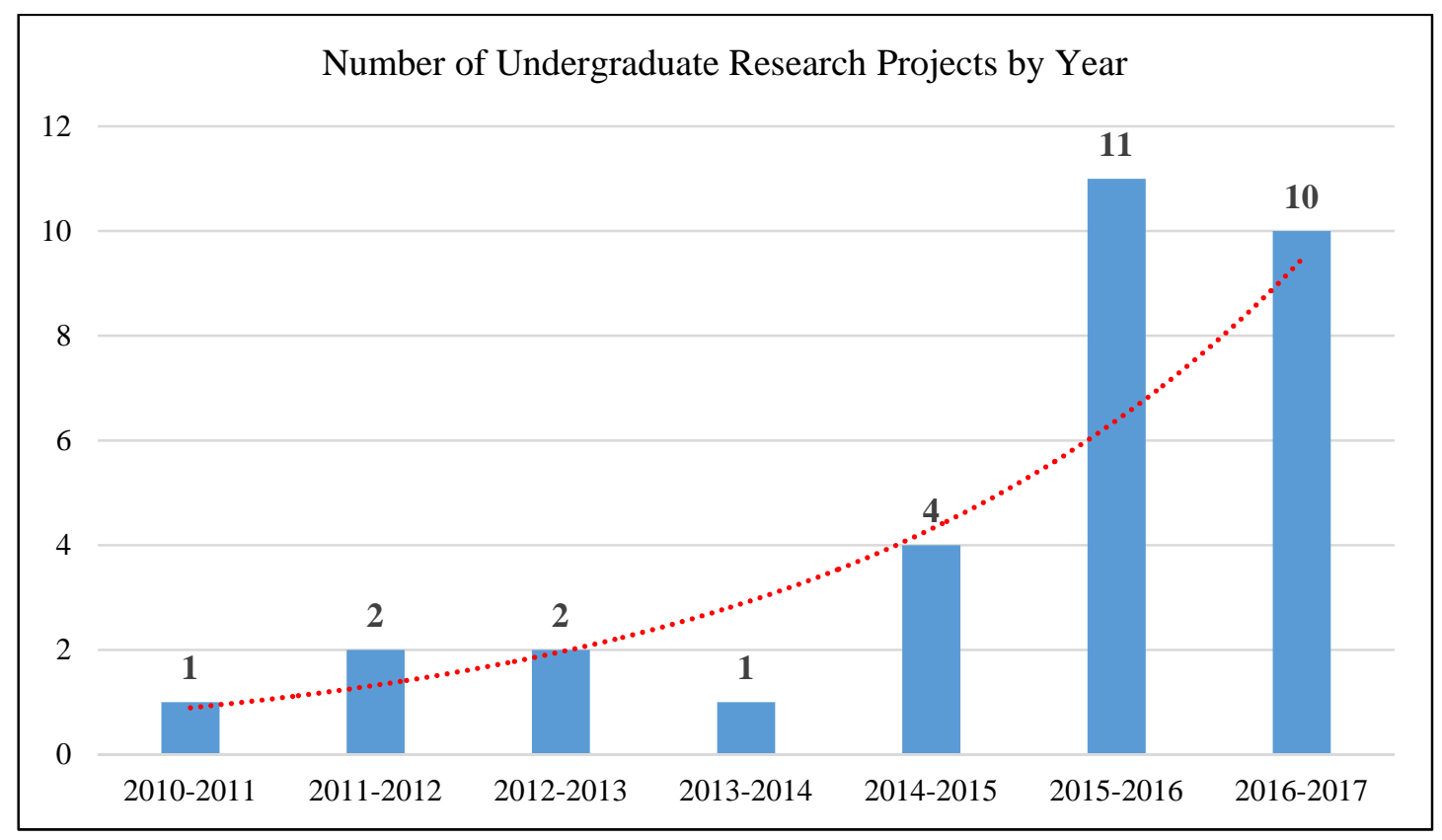

Figure 2. Number of Undergraduate Research Projects by Academic year

Tenured Faculty Development

A review of the success of focused development plans for tenured or tenure-track faculty is undeniable. A more refined question would be the effect on each faculty level, especially the full professors. They are receiving the least amount of support because as they attain higher academic rank they should have developed (expected to develop) a sustainable research network that would provide much of the necessary future development funds. However, when installing the current funding levels noted above, the senior faculty were not doing 
much research or scholarship. Additionally, the current leadership team had been hired from within and were peers of the same senior faculty not producing scholarship.

The leadership team needed a plan on how to move the inactive associate and full professors (90-5-5) from off the stop mark to scholarship producing faculty as required of each new hire (60-20-20). Since each faculty member must submit a development plan for the New Year as they submit their successes for the past year, the leadership team is able to counsel and mentor faculty toward professional development goals that match the new faculty work load model of 60-20-20. Tenure-track assistant professors and associate professors on track to reaching full professor by established timelines are less resistant to guidance since the department head writes their support documents. Also faculty who continue and bifurcate off of the research from their dissertation are establishing the small funding (even at a teaching focused school) to allow them to become financially self-sufficient for future faculty development opportunities. The most difficult group is those that have not continued (teaching focused school) or gradually stopped producing new scholarship. The question was how to make progress with them?

The leadership team quickly realized that while they had to reduce the available funding for the senior group, they are also the most likely to have stopped producing scholarship. Review of the three previous submissions for annual evaluations by senior faculty showed no new research. However, the Provost was requiring all faculty to have a 60-20-20 workload or be reclassified to a different workload or faculty classification (senior lecturer - loss of tenure) that might limit merit and long-term employability.

Each faculty member was counseled and mentored to develop a plan with a three year cycle of funding to rebuild their scholarship production. In the first year an area of exploration would be determined, and professional development opportunities explored, and one selected to attend with a total cost of up to $\$ 2500$. Through this activity, the goal was to establish a research area that could be funded the next year with a research grant of up to $\$ 3000$. Other faculty working in associated areas were linked with this senior faculty member to provide some mentoring to move the research forward. In some cases, the faculty combine funds and work together collecting the data as well as producing the scholarship. The third year, the senior faculty member is given up to $\$ 2500$ to support travel to present the results if the paper is accepted. Every three years the cycle is continued in an effort to retrain and grow faculty to produce research and scholarship as part of the 60-20-20 workload model. The success is shown in Table 4.

Table 4. Scholarship by Senior Faculty From 2011-2016 ${ }^{8}$

\begin{tabular}{|l|c|c|c|c|c|c|c|c|}
\hline & $\begin{array}{c}\text { Student Credit } \\
\text { Hour/Faculty }\end{array}$ & $\begin{array}{c}\text { Advisees/ } \\
\text { Faculty }\end{array}$ & $\begin{array}{c}\text { Scholarship } \\
\text { School } \\
\text { Wide }\end{array}$ & $\begin{array}{c}\text { Average/ } \\
\text { Faculty }\end{array}$ & $\begin{array}{c}\text { Senior } \\
\text { Faculty } \\
\text { scholarship }\end{array}$ & $\begin{array}{c}\text { Percentage } \\
\text { versus All } \\
\text { Faculty }\end{array}$ & $\begin{array}{c}\text { ExCEEd } \\
\text { Participant } \\
\text { Scholarship }\end{array}$ & $\begin{array}{c}\text { Percentage } \\
\text { versus all } \\
\text { Faculty }\end{array}$ \\
\hline 2012 & 349.7 & 27.4 & 47.5 & 2.0 & $\mathbf{6 . 5}$ & $\mathbf{1 3 . 7}$ & 10.5 & 22.1 \\
\hline 2013 & 358.7 & 30.5 & 41 & 1.7 & $\mathbf{5 . 0}$ & $\mathbf{2 0 . 7}$ & 4.25 & 10.4 \\
\hline 2014 & 366.7 & 29.6 & 89.8 & 3.2 & $\mathbf{2 6 . 5}$ & $\mathbf{2 9 . 5}$ & 32.5 & 36.2 \\
\hline 2015 & 374.2 & 29.9 & 101.5 & 3.7 & $\mathbf{3 1 . 7}$ & $\mathbf{3 1 . 3}$ & 70.25 & 69.5 \\
\hline 2016 & 369.1 & 22.0 & 146.3 & 4.6 & $\mathbf{4 5 . 5}$ & $\mathbf{3 1 . 1}$ & 109.5 & 74.8 \\
\hline
\end{tabular}


The School of Engineering has had one faculty with less than 5 years to retirement choose to move to an untenured lecturer position with a term contract so he can continue to focus on teaching and not scholarship (or post tenure probation) within the last years of employment. This type of change also supports the additional change to move the faculty from nearly 100 percent tenured or tenure tracked down to 75 percent with 25 percent being untenured faculty. It has also moved a few faculty already retirement eligible to retire and allow new faculty hires to assume the 60-20-20 work load and increase scholarship production. Since the funding was in place to support each to improve scholarship performance, none expressed any thoughts of the change being necessarily unfair. Change was inevitable with reduction in state funding and the entrenchment required during the most recent recession.

Another technique used with senior faculty is for them to mentor new tenure-tracked faculty in teaching while aligning them to do scholarship and research together, especially research the institution is supporting with the $\$ 3000$ grants. The ultimate goal of better prepared students' needs to be the focus for all funds provided for faculty professional development, no matter what type of faculty title they may have. The School continues to seek more undergraduate research opportunities.

The Dean who has been a part of the ASCE ExCEEd Teaching Workshop for many years hosts a two day Mini-ExCEEd Teaching Workshop on campus every other year (see schedule at Appendix 1). All new tenure-tracked faculty hired since the last workshop must attend and an open invitation is provided to all engineering faculty and adjuncts as well as all STEM faculty on campus. Each year senior faculty attend to improve teaching. They also make connections with new STEM faculty from across campus opening up additional research/scholarship opportunities. Two years ago the Physics Department Head and Computer Science Program Director attended. This year the Civil Engineering and Mechanical Engineering Department heads attended. Each struck up conversations with new faculty in other departments during breaks and lunch. These types of settings lead to improved teaching, especially in courses taught in one department for students in another (such as statics by civil engineering faculty for students in mechanical engineering), but also open discussions about teaching and research passions in non-threatening situations between senior and newly minted faculty. These department heads noted they easily determined which of their senior faculty they could possibly connect with the new faculty for research opportunities. Table 4 also depicts the scholarship output by faculty who have attended the Mini-ExCEEd Teaching Workshop. These faculty note an improvement in lesson preparation, student performance, and enjoyment in teaching which they state has led to more efficiencies in both teaching and scholarship (clearly seen in Table 4, last column). Additionally, within two semesters these new faculty student evaluations are at or exceed the departmental averages tracked by the institution.

\section{Conclusions}

Any person who provides their services in the mission of the college or school or department deserves to be supported in developing the necessary skills to be the best employee possible. What is necessary is leadership who support and take the time to ensure the annual 
assessment of each person includes the development of a plan to attend conferences, training, or to conduct research to meet any noted weaknesses or deficiencies or areas to develop new skills needed in the future as the organization morphs to meet changing needs. Many times we as leaders note the areas for improvement, but seldom place resources to actually develop the required skills. This includes senior faculty who might have stopped producing scholarship. The goal of development training: leaders must project confidence in their people and provide them the resources to accomplish the mission at desired levels. Sometimes the resources must be actual training - even for senior faculty.

Table 4 presents the positive change in scholarship production for senior faculty when required to submit an annual development plan and provided resources in a cyclic process to develop research topics, conduct research, and present research. It also presents the scholarship production for faculty who are focused on improving their teaching capabilities. These positive changes are possible with leadership willing to do the heavy lifting of detailed assessment of each faculty member, mentoring and coaching to develop detailed development plans, and the willingness to raise and obligate the necessary development funds.

Bibliography

1. http://www4.ncsu.edu/unity/lockers/users/f/felder/public/NETI.html

2. http://www.asce.org/exceed/

3. Web search of "faculty 60-20-20 workload models" results in over 100 references to schools throughout the country using varying teaching loads with many using the 60-20-20 model.

4. The Citadel Faculty Handbook, http://www.citadel.edu/root/images/policies/facultymanual.pdf

5. Suchan, W.K, Blair, J.R., Fairfax, D. Aoda, B.S., Huggins, K.L., Lemanski, M.J., “Faculty Development in Information Technology Education,” SIGITE ’06, pg. 15-18, 2006.

6. Boice, Robert, Advice for New Faculty Members, Allyn and Baron, Needham Heights, MA, 2000.

7. Data submitted to the Committee on Higher Education for The Citadel as well as is available within Institutional Assessment Reports for The Citadel, http://www.citadel.edu/root/assessment-assessment/institutional.

8. Data collected annually within the School of Engineering workload model spreadsheet. 


\begin{tabular}{|l|l||}
\hline SCHEDULE \\
\hline
\end{tabular}

Thursday, January 5, 2017

\begin{tabular}{|c|c|c|c|c|}
\hline TIME & EVENT & TOPIC & LEAD & REMARKS \\
\hline 8:00-8:20 & Assessment I & $\begin{array}{l}\text { Introductions and } \\
\text { background knowledge probe }\end{array}$ & Welch & $\begin{array}{l}\text { Participants fill out a background knowledge probe } \\
\text { and give to mentors. No names please (will try to do } \\
\text { this prior to the workshop). }\end{array}$ \\
\hline 8:20-9:00 & Seminar I & Teaching and Learning & Welch & $\begin{array}{l}\text { Interactive period establish the need for effective } \\
\text { teaching. }\end{array}$ \\
\hline 9:05-10:05 & $\begin{array}{l}\text { Demonstration } \\
\text { Class I }\end{array}$ & $\begin{array}{l}\text { Application of Fundamental } \\
\text { Teaching Techniques }\end{array}$ & Welch & $\begin{array}{l}\text { Truss Analysis I - A technical class to demonstrate } \\
\text { teaching techniques. }\end{array}$ \\
\hline $\begin{array}{l}10: 05- \\
10: 35\end{array}$ & Assessment II & Assessment of Demo Class & Rabb & $\begin{array}{l}\text { Participants are led in the assessment of the demo class. } \\
\text { This event sets the tone for assessment of future classes. }\end{array}$ \\
\hline 1035-11:00 & Break & & & \\
\hline $\begin{array}{l}11: 00- \\
11: 50\end{array}$ & Seminar II & $\begin{array}{l}\text { Effective Learning and } \\
\text { Teaching }\end{array}$ & Welch & $\begin{array}{l}\text { Interactive period to introduce the elements of } \\
\text { effective teaching }\end{array}$ \\
\hline $12: 00-1: 00$ & Lunch & & & \\
\hline $1: 00-1: 40$ & Seminar III & Speaking & Welch & $\begin{array}{l}\text { Your voice as an effective teaching tool and eliciting } \\
\text { positive emotion in the classroom }\end{array}$ \\
\hline $1: 40-2: 30$ & Seminar IV & Learning Objectives & Rabb & $\begin{array}{l}\text { Learning objectives to communicate expectations to } \\
\text { students }\end{array}$ \\
\hline $2: 30-2: 45$ & Break & & & \\
\hline $2: 45-4: 00$ & $\begin{array}{l}\text { Seminar V } \\
\text { Lab I }\end{array}$ & $\begin{array}{l}\text { Planning a Class II: Board } \\
\text { Notes }\end{array}$ & Welch & $\begin{array}{l}\text { The preparation of lesson notes using the board note } \\
\text { format. }\end{array}$ \\
\hline $4: 00-4: 15$ & & $\begin{array}{l}\text { Wrap-up and review of } \\
\text { tomorrow's schedule }\end{array}$ & Welch & \\
\hline
\end{tabular}




\section{SCHEDULE}

Friday, January 6, 2017

\begin{tabular}{|c|c|c|c|c|}
\hline TIME & EVENT & TOPIC & LEAD & REMARKS \\
\hline 8:00-8:10 & & Announcements & Welch & \\
\hline 8:10-9:00 & $\begin{array}{l}\text { Seminar VI } \\
\text { Lab II }\end{array}$ & $\begin{array}{l}\text { Using the White/Chalk } \\
\text { Boards }\end{array}$ & $\begin{array}{l}\text { Welch, Rabb, } \\
\text { Grayson }\end{array}$ & $\begin{array}{l}\text { Writing to communicate, Effective use of various } \\
\text { presentation media. Chalk Board Aerobics }\end{array}$ \\
\hline 10:00-10:15 & Break & & & \\
\hline $10: 15-11: 15$ & $\begin{array}{l}\text { Demonstration } \\
\text { Class II }\end{array}$ & $\begin{array}{l}\text { Application of Fundamental } \\
\text { Teaching Techniques II }\end{array}$ & Grayson & $\begin{array}{l}\text { Trusses II - A technical class to demonstrate teaching } \\
\text { techniques and to demonstrate how more techniques } \\
\text { from the ExCEEd model can be employed in the } \\
\text { classroom. }\end{array}$ \\
\hline $11: 15-12: 00$ & Assessment & Assessment of Demo Class & Welch & Participants will prepare a formal assessment of a class \\
\hline $12: 00-1: 00$ & Lunch & & & \\
\hline $1: 00-1: 45$ & Seminar VIII & Questioning & Welch & $\begin{array}{l}\text { Questioning to involve students and make contact } \\
\text { with them }\end{array}$ \\
\hline $3: 45-4: 15$ & Wrap-up & $\begin{array}{l}\text { Workshop assessment \& } \\
\text { Conclusion }\end{array}$ & Welch & \\
\hline
\end{tabular}

